\title{
Proposed Modifications to ACI 318-95 Tension Development and Lap Splice for High-Strength Concrete
}

\author{
by Atorod Azizinamini, David Darwin, Rolf Eligehausen, Rob Pavel, and S. K. Ghosh
}

\begin{abstract}
Safety concerns and a lack of test data are responsible for the current upper limit of 100 psi on the square root of the concrete compressive strength for use in calculating tension development and lap splice lengths. Based on recent research on the lap splice strength of reinforcing bars in high-strength concrete, modifications to current design criteria are formulated that will allow removal of the limit on the square root of the compressive strength, ensure adequate ductility and bond, and improve the overall safety of the tension development and lap splice criteria in ACI 318-95 for concrete with strengths above 10,000 psi. The result of the analyses used to develop the new design criteria indicate that increasing lap splice length, without providing transverse reinforcement, does not provide an adequate level of ductility in highstrength concrete members. Adequate ductility can be achieved by using a minimum splice length, as defined by ACI 318-95 for beams without transverse reinforcement, plus a minimum quantity of transverse reinforcement over the tension development/lap splice length with an area equal to $50 \%$ of the area of the bars being developed/spliced.
\end{abstract}

Keywords: bond (concrete to reinforcement); building codes; deformed reinforcement; high-strength concrete; reinforcing steels; splicing; structural engineering.

\section{INTRODUCTION}

Due to safety concerns and a lack of test data, the ACI Building Code (ACI 318-95) ${ }^{1}$ has an upper limit of 100 psi on $\sqrt{f_{c}^{\prime}}$ for use in calculating tension development and splice lengths of reinforcing bars $\left(f_{c}^{\prime}\right.$ is the specified compressive strength of concrete; $f_{c c}^{\prime}$ and $\sqrt{f_{c}^{\prime}}$ are expressed in units of stress). Recent research on highstrength concrete ${ }^{2,3}$ has demonstrated that, without confining transverse reinforcement, the limitation on $\sqrt{f_{c}^{\prime}}$ is justified. The research has also demonstrated that, even with the limit on the $\sqrt{f_{c}{ }^{\prime}}$, bond failure, which is normally nonductile, becomes especially brittle and even explosive as concrete strengths approach 15,000 psi $(100 \mathrm{MPa})$. While other research ${ }^{4}$ indicates that the ACI development and splice provisions become progressively less accurate as $f_{c}^{\prime}$ increases above 7000 to $10,000 \mathrm{psi}$ (50 to $70 \mathrm{MPa}$ ), it is not the goal of this paper to introduce new design expressions, but rather to provide modifications to the current design criteria that will: 1) allow removal of the limit on $\sqrt{f_{c}{ }^{\prime}} ; 2$ ) ensure adequate ductility in bond; and 3) improve the overall safety of the development and splice criteria in ACI 318-95 for concretes with strengths above $10,000 \mathrm{psi}(70 \mathrm{MPa})$.

The changes proposed in this paper rest heavily on the work of Azizinamini et al. ${ }^{2,3}$ on splice strength in highstrength concrete. A typical test specimen is shown in Fig. 1. One of the principal goals of their study was to determine the combination of splice length and confining transverse reinforcement that would provide not only adequate strength, but a displacement ductility $\mu$ that would ensure

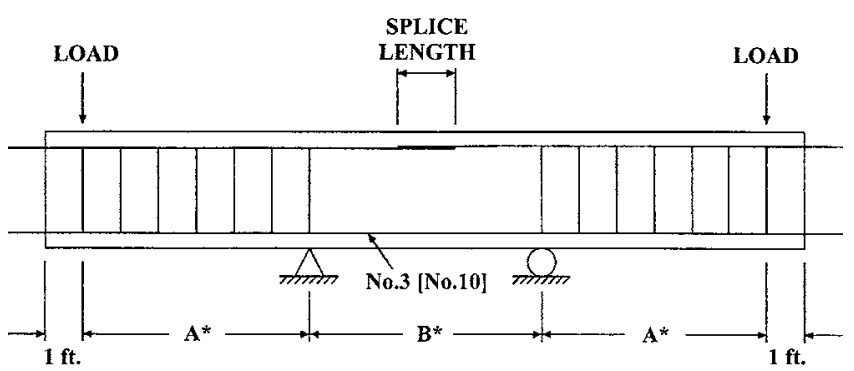

Elevation
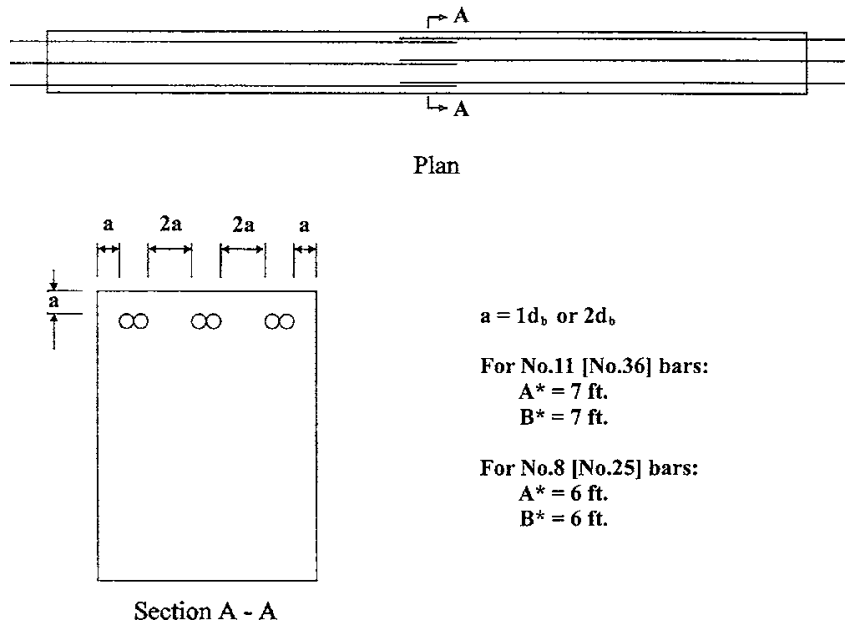

Fig. 1-Test specimen.

adequate warning of failure. As illustrated in Fig. 2, displacement ductility is defined as the ratio of the maximum deflection $\Delta_{\max }$ to the yield deflection $\Delta_{y}$.

In their study, Azizinamini et al. ${ }^{2,3}$ evaluated splice strengths of No. 8 and No. 11 (No. 25 and No. 36) bars with concrete covers of 1 bar diameter $\left(d_{b}\right)$ and clear spacings of $2 d_{b}$, and with concrete covers of $2 d_{b}$ and clear spacings of $4 d_{b}$. Of the test specimens, those containing No. 11 bars with a $1 d_{b}$ concrete cover provided the lowest ductility. With the proper combination of splice length and confining transverse reinforcement, however, these specimens were able to attain a displacement ductility of 2.7 at failure without splitting the concrete cover within the splice region and, thus, provide ample warning before failure.

ACI Structural Journal, V. 96, No. 6, November-December 1999

Received March 23, 1998, and reviewed under Institute publication policies. Copyright (C) 1999, American Concrete Institute. All rights reserved, including the making of copies unless permission is obtained from the copyright proprietors. Pertinent discussion including author's closure, if any, will be published in the September-October 2000 ACI Structural Journal if the discussion is received by May 1, 2000. 
Atorod Azizinamini is an associate professor of civil engineering and Director of National Bridge Research Organization at the University of Nebraska-Lincoln. He received his $B S$ from the University of Oklahoma and $M S$ and $P h D$ from the University of South Carolina. He is a member of several ACI Committees, and is secretary of ACI Committee 408, Bond and Development of Reinforcement. His research interests include design issues related to high-strength concrete and seismic behavior of steel concrete composite building systems.

David Darwin, FACI, is the Deane E. Ackers Professor of Civil Engineering and Director of the Structural Engineering and Materials Laboratory at the University of Kansas. He is a past member of the ACI Board of Direction and the Technical Activities Committee, and is past-president of the Kansas Chapter of ACI. He is also past-chairman of the Publications Committee and the Concrete Research Council. He chairs the TAC Technology Transfer Committee and serves on ACI Committees 224, Cracking; 408, Bond and Development of Reinforcement; 446, Fracture Mechanics; and Joint ACI-ASCE Committees 445, Shear and Torsion; and 447, Finite Element Analysis of Reinforced Concrete Structures.

ACI member Rolf Eligehausen is a professor and department head at the Institute for Building Materials, University of Stuttgart. He studied at the University of Braunschweig and obtained his PhD from the University of Stuttgart in 1979. He is a member of ACI Committees 355, Anchorage to Concrete; 408, Bond and Development of Reinforcement; and 446, Fracture Mechanics.

Rob Pavel was formerly a graduate student at the University of Nebraska-Lincoln. He is currently a structural engineer with Wilson Concrete Industries in Omaha, Neb.

S. K. Ghosh, FACI, heads his own consulting practice, S. K. Ghosh Associates Inc., Mt. Prospect, Ill. and Redwood City, Calif. He is a member of ACI Technical Activities Committee and ACI Committees 318, Standard Building Code; 435, Deflection of Concrete Building Structures, of which he is a former chairman, and 442, Response to Concrete Buildings to Lateral Forces.

Using this as a starting point, the principal goal of this paper is to establish general criteria and implement code language for development/splice length and transverse reinforcement to ensure both adequate displacement ductility and strength for high-strength concrete members. The resulting criteria represent a departure from the usual approach to development and splice design.

Full details of the tests are presented by Azizinamini et al. ${ }^{2,3}$ and are summarized in Appendix A.

\section{Displacement ductility}

\section{DEVELOPMENT OF CRITERIA}

Desirable minimum values of displacement ductility $\mu$ can be established for the full range of tests by Azizinamini et al. ${ }^{2,3}$ using the value of 2.7 obtained for the specimens with No. 11 (No. 36) bars with $1 d_{b}$ cover. The latter specimens had a reinforcement ratio, $\rho=A_{s} / b d$, of 0.0164 , where $A_{s}$ is the total area of longitudinal reinforcement outside of the splice region, $b=$ width of the cross section, and $d=$ distance from the centroid of the tension steel to the extreme compression fiber of the concrete. Reducing $\rho$ results in an increase in the curvature at failure and, thus, in the displacement ductility. The target ductilities for the other test specimens in Reference 2 and 3 are established by multiplying $\mu=2.7$ by the ratio of 0.0164 to the reinforcement ratio for those specimens. The values for the four combinations of bar size and cover/clear spacing are shown in Table 1. They range from 2.7 for specimens containing No. 11 bars with $1 d_{b}$ cover and $2 d_{b}$ clear spacing, to 4.5 for specimens containing No. 8 bars with $2 d_{b}$ cover and $4 d_{b}$ clear spacing.

\section{Behavior of specimens without stirrups}

Before establishing minimum requirements for transverse reinforcement, it is worth determining whether adequate ductility can be provided when using high-strength concrete simply by increasing development/splice length without the

\footnotetext{
*The Appendix is available in xerographic or similar form from ACI headquarters, where it will be kept permanently on file, at a charge equal to the cost of reproduction plus handling at time of request.
}

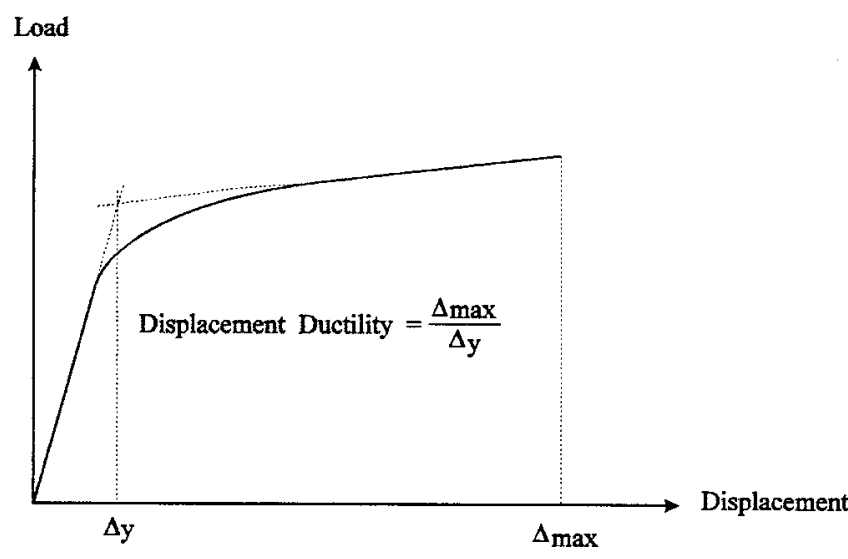

Fig. 2-Definition of displacement ductility.

Table 1-Section properties and target minimum displacement ductilities

\begin{tabular}{c|c|c|c|c|c}
\hline & \multicolumn{2}{|c|}{ Beam* cross section } & $\begin{array}{c}\text { Longitudinal } \\
\text { reinforcement } \\
\text { ratio } \rho\end{array}$ & $\begin{array}{c}\text { Target } \\
\text { displacement } \\
\text { ductility } \mu^{\dagger}\end{array}$ \\
\cline { 2 - 5 } $\begin{array}{c}\text { No. 8 (No. 25) bars } \\
\text { with } 1 d_{b} \text { cover }\end{array}$ & 9 & 14.5 & 16 & 0.0121 & 3.6 \\
\hline $\begin{array}{c}\text { No. 8 (No. 25) bars } \\
\text { with } 2 d_{b} \text { cover }\end{array}$ & 12 & 13.5 & 16 & 0.0098 & 4.5 \\
\hline $\begin{array}{c}\text { No. 11 (No. 36) bars } \\
\text { with } 1 d_{b} \text { cover }\end{array}$ & 18 & 15.9 & 18 & 0.0164 & 2.7 \\
\hline $\begin{array}{c}\text { No. 11 (No. 36) bars } \\
\text { with } 2 d_{b} \text { cover }\end{array}$ & 18 & 14.5 & 18 & 0.0120 & 3.7 \\
\hline
\end{tabular}

* $b=$ width; $d=$ effective depth; and $h=$ total depth.

$\dot{\dagger}=2.7 \times 0.0164 / \rho$.

Note: 1 in. $=25.4 \mathrm{~mm}$

use of confining stirrups. As demonstrated in Fig. 3(a) and (b) for $15,000 \mathrm{psi}(100 \mathrm{MPa})$ concrete, adequate ductility cannot be provided by increasing splice length alone. ${ }^{2,3}$ Figure 3(a) and (b) compare the displacement ductility $\mu$ with splice length for No. 11 and No. 8 (No. 36 and No. 25) bars, respectively. In the figures, data points for each combination of bar size and cover/clear spacing are connected by straight lines. The figures also contain horizontal lines representing the target values of $\mu$ in Table 1 . The figures contain vertical lines corresponding to the splice lengths for each bar size and cover required by ACI 318-95 (without setting a limit on $\left.\sqrt{f_{c}{ }^{\prime}}\right)$. Member ductility is adequate if the target value of $\mu$ is attained with a splice length that is less than or equal to the splice length required by ACI 318-95. As shown in Fig. 3(a) and (b), this is not accomplished for any of the four combinations of bar size and cover/clear spacing illustrated. This is especially clear for the No. 11 bars with $1 d_{b}$ cover that do not reach the target ductility of 2.7 , even at 1.78 times the design splice length.

\section{Behavior of specimens with stirrups}

The amount of transverse reinforcement needed to provide adequate ductility depends on the splice length. Figure 4 through 7 compare the displacement ductilities achieved for each combination of bar size and cover/clear spacing with the amount of transverse reinforcement provided for the specimens. ${ }^{2,3}$ Transverse reinforcement is expressed as the ratio of the total area of transverse reinforcement provided within the splice length $A_{s p}$ to a quantity of transverse reinforcement equal to $60 \%$ of the total area of the bars being 


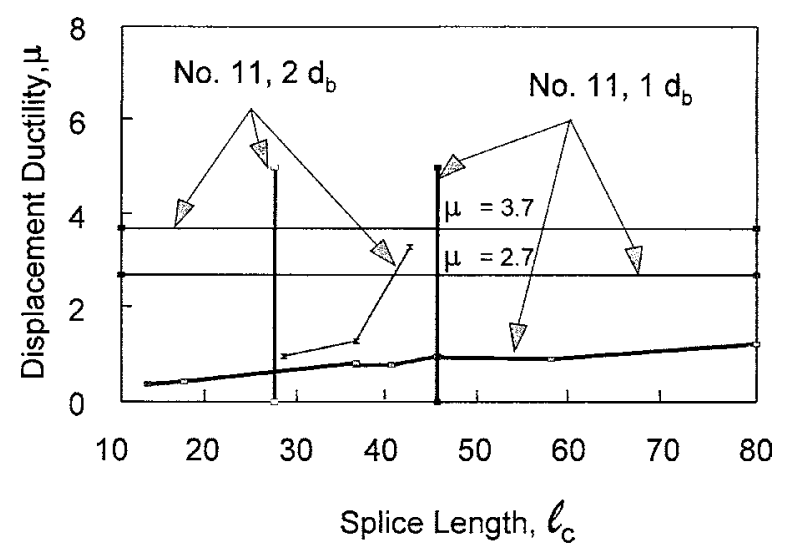

(a)

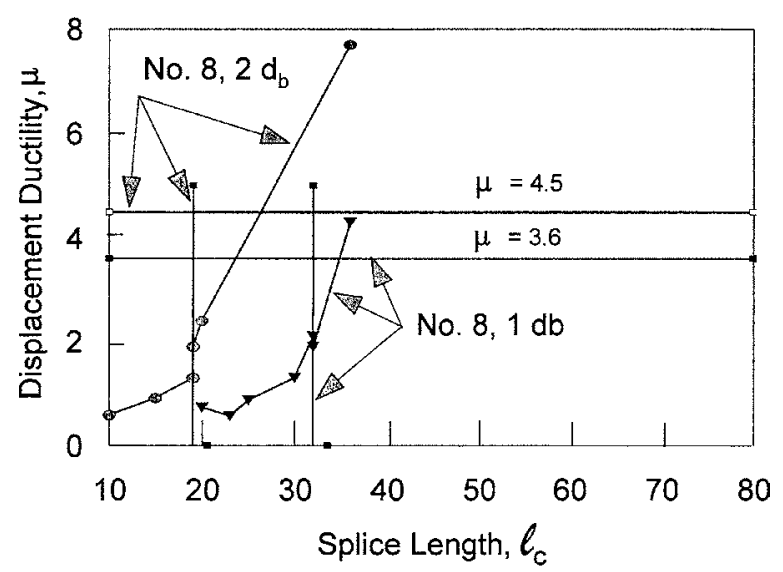

(b)

Fig. 3-Displacement ductility versus splice length for: (a) No. 11 (No. 36) bars; and (b) No. 8 (No. 25) bars.

spliced, $A_{s r}=0.6 n A_{b}$, in which $n=$ the number of spliced bars, and $A_{b}=$ the area of a single spliced bar. ${ }^{\dagger}$

Each data point in Fig. 4 through 7 corresponds to an individual test. ${ }^{2,3}$ In the figure, data points corresponding to specimens with the same splice lengths are connected using straight lines between points. Three splice lengths are used for each combination of cover/clear spacing for No. 11 (No. 36) bars and two splice lengths are used for each combination for No. 8 (No. 25) bars. The three sets of lines in Fig. 4 represent specimens with No. 11 (No. 36) bars with $1 d_{b}$ cover and splice lengths of 40, 45, and 57.5 in. (1020, 1140, and $1460 \mathrm{~mm})$. Because the specimens without stirrups $\left(A_{s p} / A_{s r}=\right.$ 0 ) failed before exhibiting substantial ductility, their ductility is defined as the ratio of the maximum bar stress at failure to the yield strength of the bars.

The values of $A_{s p} / A_{s r}$ corresponding to the target ductilities are represented by the intersection of the lines connecting the data points with the horizontal lines for the target values for $\mu$. In Fig. 4, the values of $A_{s p} / A_{s r}$ needed to achieve $\mu=2.7$ are $0.627,0.453$, and 0.320 for splice lengths of 40,45 , and 57.5 in. (1020, 1140, and $1460 \mathrm{~mm}$ ), respectively. Similar results are presented for the other combinations of bar size and cover/clear spacing in Fig. 5 through 7. For No. 11 (No. 36) bars with $2 d_{b}$ cover, the values of $A_{s p} / A_{s r}$ needed to

\footnotetext{
${ }^{\dagger} A_{s r}$ approximates the amount of confining transverse steel needed to balance the splitting forces exerted by a longitudinal bar with a 45 degree rib face angle and a zero coefficient of friction between the bar and the surrounding medium. Stresses in the bar and in the transverse reinforcement are assumed to be equal. ${ }^{4}$
}

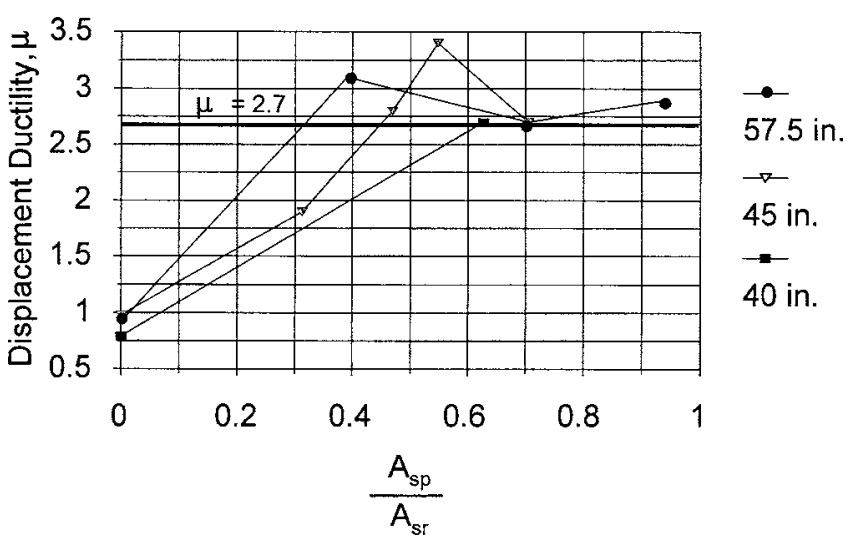

Fig. 4-Displacement ductility versus $\mathrm{A}_{\mathrm{sp}} / \mathrm{A}_{\mathrm{sr}}\left(\mathrm{A}_{\mathrm{sp}}=\right.$ total area of transverse reinforcement within splice length; $\mathrm{A}_{\mathrm{sr}}=$ $60 \%$ of total area of bars being spliced) for No. 11 (No. 36) bars with $1 \mathrm{~d}_{\mathrm{b}}$ cover and $2 \mathrm{~d}_{\mathrm{b}}$ clear spacing.

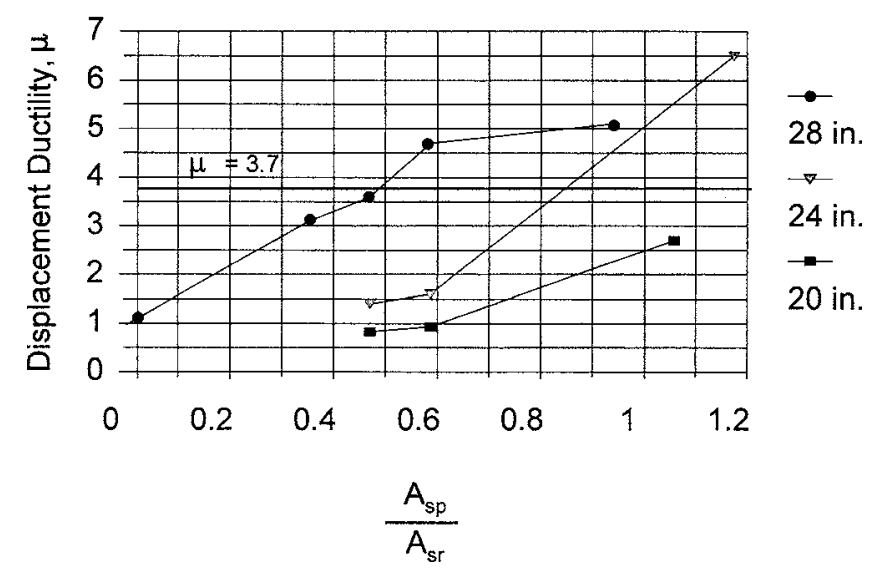

Fig. 5-Displacement ductility versus $\mathrm{A}_{\mathrm{sp}} / \mathrm{A}_{\mathrm{sr}}\left(\mathrm{A}_{\mathrm{sp}}=\right.$ total area of transverse reinforcement within splice length; $\mathrm{A}_{\mathrm{sr}}=$ $60 \%$ of total area of bars being spliced) for No. 11 (No. 36) bars with $2 \mathrm{~d}_{\mathrm{b}}$ cover and $4 \mathrm{~d}_{\mathrm{b}}$ clear spacing.

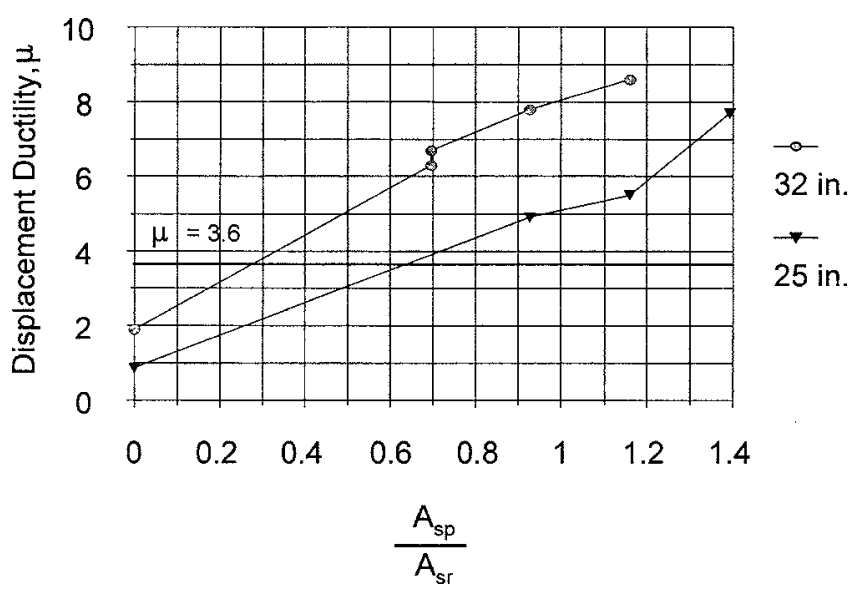

Fig. 6-Displacement ductility versus $\mathrm{A}_{\mathrm{sp}} / \mathrm{A}_{\mathrm{sr}}\left(\mathrm{A}_{\mathrm{sp}}=\right.$ total area of transverse reinforcement within splice length; $\mathrm{A}_{\mathrm{sr}}=$ $60 \%$ of total area of bars being spliced) for No. 8 (No. 25) bars with $1 \mathrm{~d}_{\mathrm{b}}$ cover and $2 \mathrm{~d}_{\mathrm{b}}$ clear spacing.

achieve $\mu=3.7$ are $1.325,0.839$, and 0.481 for splice lengths of 20,24 , and 28 in. $(510,610$, and $710 \mathrm{~mm})$, respectively. For No. 8 (No. 25) bars with $1 d_{b}$ cover, the values of $A_{s p} / A_{s r}$ for $\mu=3.6$ are 0.629 and 0.269 for splice lengths of 25 and 


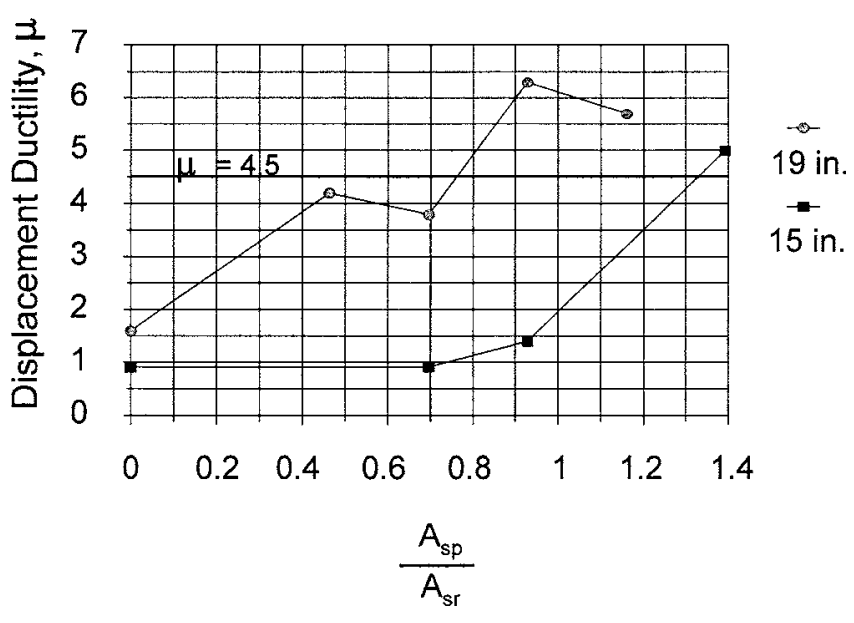

Fig. 7-Displacement ductility versus $\mathrm{A}_{\mathrm{sp}} / \mathrm{A}_{\mathrm{sr}}\left(\mathrm{A}_{\mathrm{sp}}=\right.$ total area of transverse reinforcement with splice length; $\mathrm{A}_{\mathrm{sr}}=$ $60 \%$ of total area of bars being spliced) for No. 8 (No. 25) bars with $2 \mathrm{~d}_{\mathrm{b}}$ cover and $4 \mathrm{~d}_{\mathrm{b}}$ clear spacing.

Table 2-Required total area of stirrups for ductile failure

\begin{tabular}{c|c|c}
\hline Specimen type & $\begin{array}{c}A_{s p} / A_{s r} \text { required to } \\
\text { achieve target } \\
\text { displacement ductility }\end{array}$ & $\begin{array}{c}A_{s p} \text { required to } \\
\text { achieve target } \\
\text { displacement ductility }\end{array}$ \\
\hline $\begin{array}{c}\text { No. 8 (No. 25) bars with } \\
1 d_{b} \text { cover }\end{array}$ & 0.34 & $0.20 n A_{b}$ \\
\hline $\begin{array}{c}\text { No. 8 (No. 25) bars with } \\
2 d_{b} \text { cover }\end{array}$ & 0.81 & $0.48 n A_{b}$ \\
\hline $\begin{array}{c}\text { No. 11 (No. 36) bars with } \\
1 d_{b} \text { cover }\end{array}$ & 0.54 & $0.32 n A_{b}$ \\
\hline $\begin{array}{c}\text { No. 11 (No. 36) bars with } \\
2 d_{b} \text { cover }\end{array}$ & 0.59 & $0.35 n A_{b}$ \\
\hline
\end{tabular}

Note: $A_{s p}=$ total area of transverse reinforcement within splice length; $A_{s r}=0.60 n A_{b}$; $n A_{b}=$ total area of spliced bars.

32 in. (640 and $810 \mathrm{~mm}$ ), respectively, and for No. 8 (No. 25) bars with $2 d_{b}$ cover, the values of $A_{s p} / A_{s r}$ for $\mu=4.5$ are 1.328 and 0.76 for splice lengths of 15 and 19 in. (380 and $480 \mathrm{~mm})$, respectively.

These values of $A_{s p} / A_{s r}$ can now be used to determine the amount of transverse reinforcement needed to achieve the target ductilities (Table 1) as a function of splice length. To do this, the values of $A_{s p} / A_{s r}$ are plotted in Fig. 8 versus the corresponding values of $l_{s p} / l_{s r}$, where $l_{s p}$ is the actual splice length (the splice length provided), and $l_{s r}$ is the splice length required by ACI 318-95 without transverse reinforcement and neglecting limitations on $\sqrt{f_{c}^{\prime}}$. $\left(l_{s p}\right.$ is calculated using Eq. (12-1) in ACI 318-95. ${ }^{1}$ ) Figure 8 contains four curves, each representing one of the four combinations of bar size and cover/clear spacing.

Using $l_{s p} / l_{s r}=1.0$ as the basis, the values of $A_{s p} / A_{s r}$ required to achieve the target displacement ductilities range from 0.34 to 0.81 , as shown in Fig. 8. As shown in Table 2, these values, in turn, convert to total stirrup areas, $A_{s p}$ between $0.20 n A_{b}$ to $0.48 n A_{b}$.

Based on these results, it appears prudent, for 15,000 psi (104 MPa) concrete, to require a total cross-sectional area of transverse reinforcement

$$
A_{s p}=0.5 n A_{b}
$$

over a splice region.
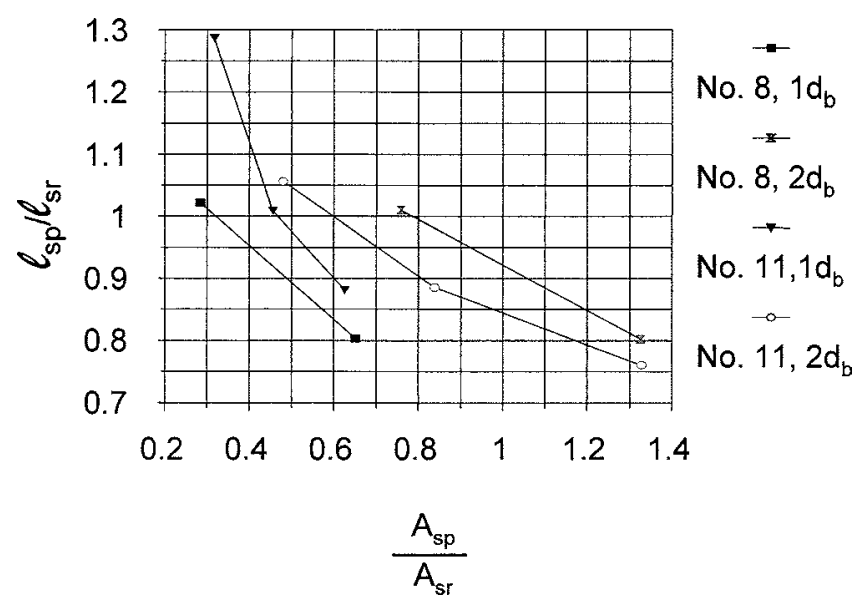

Fig. 8-Ratio of development provided $1_{\mathrm{sp}}$ to development length required by ACI 318-95 without transverse reinforcement and within no limit on $\sqrt{\mathrm{f}_{\mathrm{c}}^{\prime}}, 1_{\mathrm{sr}}$ versus $\mathrm{A}_{\mathrm{sp}} / \mathrm{A}_{\mathrm{sr}}$.

Earlier research ${ }^{5}$ indicates that adding $A_{s p}$ is equivalent to increasing the stress in a developed/spliced bar by a fixed value $\Delta f_{s}$. For conventional reinforcement

$$
\Delta f_{s}=\left(2177 t_{d} \frac{A_{s p}}{n}+66\right)^{f_{c}^{, 1 / 4}} \frac{A_{b}}{A_{b}}
$$

where $t_{d}=0.72 d_{b}+0.28$.

Based on Eq. (2), the amount of transverse reinforcement shown in Eq. (1) will increase the stress in a No. 8 (No. 25) bar by about $13,000 \mathrm{psi}(90 \mathrm{MPa})$ when $f_{c}^{\prime}=15,000 \mathrm{psi}$ (104 $\mathrm{MPa})$. This additional strength matches the increases in strength observed in Reference 2 and 3.

The minimum amount of stirrups required by Eq. (1) is based on the test data obtained from testing specimens with concrete compressive strengths of approximately 15,000 psi (104 MPa). Therefore, use of this equation for cases with concrete compressive strength of less than 15,000 psi (104 $\mathrm{MPa}$ ) will be conservative. Further, the test data and the failure hypothesis presented indicate that, as concrete compressive strength decreases, the severity of the problem with the use of higher strength concrete decreases. As a result, it is suggested that the amount of minimum stirrups required decrease in a linear manner, as the concrete strength decreases. The following equation could be used to reflect this philosophy

$$
A_{s p}=0.5 n A_{b}\left(f_{c}^{\prime} / 15,000\right)
$$

where $f_{c}^{\prime}$ has a psi unit.

The maximum spacing of stirrups used in the experimental program described in Reference 2 and 3 was 12 in. (300 mm) for specimens containing No. 11 (No. 36) bars, and 15 in. (380 $\mathrm{mm}$ ) for specimens containing No. 8 (No. 25) bars. Using the more restrictive of the two spacings, it is recommended that stirrups used to provide $A_{s p}$ have a spacing not greater than 12 in. $(300 \mathrm{~mm})$. Because the confinement provided by transverse reinforcement is based on a confining force, which can be mobilized by shear or torsion as well as bond splitting, stirrups used as shear and/or torsion reinforcement can also be used to satisfy the area of steel required in Eq. (1). The trans- 
verse reinforcement should not be smaller than a No. 3 (No. 10) bar, the smallest size used by Azizinamini et al. ${ }^{2,3}$

\section{RECOMMENDATIONS}

Based on the information provided in this paper, the following specific changes are recommended for future editions of ACI 318.

\section{Existing Section 12.1.2 of $\mathrm{ACl}$ 318-95}

"The values of $\sqrt{f_{c}^{\prime}}$ used in this chapter shall not exceed 100 psi."

\section{Change Section 12.1.2 of the $\mathrm{ACl} 318-95$ as follows:}

"When the value of $\sqrt{f_{c}^{\prime}}$ exceeds $100 \mathrm{psi}$, the requirements of Sec. 12.2.6 must be satisfied in calculating tension development or lap splice length. For other cases, the values of $\sqrt{f_{c}}$ ' used in this chapter shall not exceed 100 psi."

\section{Add a new section (Section 12.2.6) as follows:}

"When the value of $\sqrt{f_{c}}$ ' exceeds $100 \mathrm{psi}, l_{d}$ shall be calculated from either 12.2.2 or 12.2.3 with $K_{t r}=0$, and transverse reinforcement with total cross-sectional area $A_{s p}$ crossing the potential plane of splitting through the reinforcement being developed shall be provided over the tension development or tension splice length.

$$
A_{s p}=0.5 n A_{b}\left(f_{c}^{\prime} / 15,000\right)
$$

"The maximum spacing of stirrups in the longitudinal direction shall not exceed 12 in., where $d_{b}$ is the bar diameter. A minimum of three stirrups shall be used, and the minimum stirrup bar size shall be No. 3."

\section{Add new commentary (Section R12.2.6)}

"Research results show that when $\sqrt{f_{c}{ }^{\prime}}$ exceeds 100 psi, a minimum tension development or splice length equal to the value calculated without confining transverse reinforcement and without a limit on $\sqrt{f_{c}{ }^{\prime}}$ must be combined with a minimum amount of transverse reinforcement to assure adequate strength and ductility. As a minimum, No. 3 rein- forcing bars must be used as stirrups. Test results indicate that use of smaller bar sizes may result in fracturing the stirrups."2,3

\section{CONCLUSIONS}

Based on the analysis presented in this paper, it can be concluded that for high-strength concrete:

1. Increasing tension lap splice length without providing transverse reinforcement will not provide an adequate level of ductility in high-strength concrete members.

2. Adequate ductility can be achieved by using a minimum lap splice length, as defined by ACI 318-95 for beams without transverse reinforcement, plus a minimum amount of transverse reinforcement over the tension development/lap splice length with an area equal to $50 \%$ of the area of the bars being developed/spliced.

\section{ACKNOWLEDGMENTS}

The work reported in this paper is based on research performed at the University of Nebraska-Lincoln and the University of Kansas. Work at the University of Nebraska was supported by the National Science Foundation under NSF Grant No. CMS-9402311, the Portland Cement Association, and the Center for Infrastructure Research at the University of NebraskaLincoln. Research at the University of Kansas was supported by the National Science Foundation under NSF Grants No. MSS-9021066 and CMS-9402563, the Civil Engineering Research Foundation under CERF Contract No. 91-N6002, ABC Coating, Inc., AmeriSteel, Birmingham Steel Corp., Chapparal Steel Co., Fletcher Coating Co., Florida Steel Corp., North Star Steel Co., 3M Corp., Iron Mountain Trap Rock Co., Geiger Ready Mix, and Richmond Screw Anchor Co.

\section{REFERENCES}

1. ACI Committee 318, "Building Code Requirements for Structural Concrete (ACI 318-95) and Commentary (318R-95)," American Concrete Institute, Farmington Hills, Mich. 1995, 369 pp.

2. Azizinamini, A.; Stark, M.; Roller, J. J.; and Ghosh, S. K., "Bond Performance of Reinforcing Bars Embedded in High-Strength Concrete," ACI Structural Journal, V. 90, No. 5, Sept.-Oct. 1993, pp. 554-561.

3. Azizinamini, A.; Pavel, R.; Hatfield, E.; and Ghosh, S. K., "Behavior of Spliced Reinforcing Bars Embedded in High-Strength Concrete," ACI Structural Journal, V. 96, No. 5, Sept.-Oct., 1999, pp. 826-835.

4. Eligehausen, R., "Ubergreifungsstöße zugbeanspruchter Rippenstäbe mit geraden Stabenden," Deutscher Ausschuss Fuer Stahlbeton, Berlin, 1979, 301 pp. (in German)

5. Darwin, D.; Zuo, J.; Tholen, M. L.; and Idun, E. K., "Development Length Criteria for Conventional and High Relative Rib Area Reinforcing Bars," ACI Structural Journal, V. 93, No. 3, May-June 1996, pp. 347-359. 